\title{
Mutu Minyak Jelantah dengan Adsorben Biji Salak (Salacca zalacca (Gaertn.)Voss) Menggunakan Parameter Bilangan Peroksida dan Asam Lemak Bebas
}

\author{
(Quality of Used Cooking Oil With Snake Fruit (Salacca zalacca (Gaertn.) Voss) Seed \\ Adsorbent Using Parameters of Peroxide Value and Free Fatty Acids)
}

\author{
Ihwan, Fadlia*, Syariful Anam \\ Jurusan Farmasi, Fakultas MIPA,Universitas Tadulako, Palu-Indonesia, 94118
}

\section{Article Info:}

Received: 10 July 2019

in revised form: 8 August 2019

Accepted: 4 September 2019

Available Online: 2 October 2019

Keywords:

Snake Fruit Seed

Used Cooking Oil

Peroxide Value

Free Fatty Acid

Corresponding Author:

Fadlia

Jurusan Farmasi FMIPA

Universitas Tadulako

Palu-Indonesia

Email: Fadlia_iaan@yahoo.co.id

\begin{abstract}
Quality of used cooking oil with snake fruit (Salacca zalacca (Gaertn.) Voss) seed adsorbent has been conducted. This study aims to determine the ability of snake fruit seed in reducing peroxide value and free fatty acids in used cooking oil which can improve the quality and extend usage lifespan of the used cooking oil. The oil sampled in this study was packaged cooking oil which is usually used to fry food untill $7^{\text {th }}$ frying. The oil was then neutralized using snake fruit activated charcoal. The test refers to the Indonesian National Standard (SNI) 7709: 2012 as the quality requirements of cooking oil. The results showed that snake fruit activated charcoal can reduce peroxide value as much as $56.18 \%$ and free fatty acid $76.04 \%$ in the used cooking oil.
\end{abstract}

How to cite (APA 6th Style):

Ihwan, Fadlia, \& Anam, S. (2019). Mutu Minyak Jelantah dengan Adsorben Biji Salak (Salacca zalacca (Gaertn.)Voss) Menggunakan Parameter Bilangan Peroksida dan Asam Lemak Bebas. Jurnal Farmasi Galenika :Galenika Journal of Pharmacy, 5(2),124-131. doi:10.22487/j24428744.2019.v5.i2.10070 


\begin{abstract}
ABSTRAK
Telah dilakukan penelitian analisis mutu minyak jelantah dengan netralisasi adsorben biji salak (Salacca zalacca (Gaertn.)Voss). Penelitian ini bertujuan untuk mengetahui kemampuan biji salak dalam menurunkan bilangan peroksida dan asam lemak bebas pada minyak jelantah, sehingga dapat meningkatkan kualitas minyak jelantah agar umur pemakaian minyak goreng dapat diperpanjang. Minyak yang digunakan pada penelitian ini adalah minyak goreng kemasan yang digunakan untuk menggoreng bahan pangan hingga penggorengan ke-7. Minyak tersebut dinetralisasi menggunakan arang aktif biji salak. Pengujian mengacu pada Standar Nasional Indonesia (SNI) 7709:2012 sebagai syarat mutu minyak goreng. Hasil penelitian menunjukkan bahwa arang aktif biji salak dapat menurunkan bilangan peroksida sebesar 56,18\% dan memberikan penurunan sebesar 76,04\% terhadap kadar asam lemak bebas yang terdapat pada minyak jelantah.
\end{abstract}

Kata kunci : Biji Salak, Minyak Jelantah, Bilangan Peroksida, Asam Lemak Bebas.

\section{PENDAHULUAN}

Minyak goreng digunakan secara luas di seluruh belahan dunia termasuk di Indonesia. Sebanyak 49\% dari total permintaan minyak goreng adalah untuk konsumsi rumah tangga dan sisanya untuk keperluan industri (Wijana, 2005).

Minyak goreng adalah salah satu kebutuhan pokok manusia sebagai media pengolahan makanan. Fungsi minyak goreng sangat penting dalam menciptakan aroma, rasa, warna, daya simpan serta untuk meningkatkan nilai gizi produk (Ketaren, 2008). Oleh karena itu kebutuhan akan minyak goreng terus meningkat dari tahun ketahun. Masyarakat Indonesia sangat majemuk dengan tingkat ekonomi yang berbeda-beda. Bagi masyarakat yang memiliki tingkat ekonomi menengah ke atas biasanya menggunakan minyak goreng maksimal 3 kali pemakaian, sedangkan bagi masyarakat yang mempunyai tingkat ekonomi menengah ke bawah biasanya menggunakan minyak goreng berkali-kali hingga minyak berubah warna menjadi kecoklatan bahkan kehitaman (Reski, 2012).

Pemakaian minyak goreng berulang-ulang akan mengakibatkan penurunan kualitas minyak yang ditandai dengan perubahan warna menjadi gelap, aroma menjadi kurang enak, kadar asam lemak bebas dan bilangan peroksida yang tinggi (Kusumastuti, 2004). Selain itu, akan terjadi penurunan nilai gizi dari bahan yang digoreng. Hal ini dikarenakan saat dipanaskan pada suhu tinggi disertai kontak dengan udara akan menyebabkan minyak mengalami perubahan kimia seperti proses hidrolisis, oksidasi, dan polimerisasi. Proses oksidasi dan polimerisasi dapat merusak sebagian vitamin dan asam lemak esensial yang terdapat dalam minyak sehingga dapat mengakibatkan keracunan dalam tubuh dan berbagai macam penyakit, seperti pengendapan lemak dalam pembuluh darah dan kanker (Ketaren, 2008).

Penggunaan minyak secara berulang biasanya dilakukan pula oleh para pedagang makanan kaki lima karena alasan ekonomi, di mana mereka merasa rugi jika minyak goreng tersebut hanya digunakan sekali, dan harus dibuang dan diganti dengan minyak yang baru (Yustinah, 2011).

Dengan melihat hal tersebut, maka peneliti tertarik untuk mendaur ulang minyak yang telah digunakan berulang (jelantah) dengan menggunakan adsorben. Penggunaan adsorben merupakan metode alternatif dalam pemurnian minyak jelantah. Metode ini efektif dan murah karena dapat memanfaatkan produk samping atau limbah pertanian. Salah satu produk samping pertanian yang berpotensi sebagai adsorben adalah biji salak. Dari hasil penelitian yang dilakukan oleh Kurniadin \& Murdiono (2011), dengan parameter pengujiannya yaitu uji organoleptis melihat penampakan warna. Hasil yang diperoleh menunjukkan bahwa adsorben biji salak mampu menyerap partikel koloid pada minyak jelantah serta menjadi penyerap warna yang efektif dengan jumlah penyerapan warna sebesar $97,4 \%$.

Selain itu penelitian pemurnian minyak jelantah telah dilakukan pula oleh Rahayu (2014), menggunakan sabut dan tempurung kelapa sebagai adsorben dengan parameter pengujiannya yaitu, uji bilangan peroksida 
dan asam lemak bebas. Dari penelitian tersebut diperoleh data bahwa adsorben sabut kelapa lebih efektif memberi penurunan kadar asam lemak bebas dan peroksida dibandingkan adsorben tempurung kelapa dengan persentase penurunannya sebesar 75,73\% terhadap kadar asam lemak bebas dan penurunan sebesar 93,39\% terhadap kadar peroksida pada minyak jelantah.

Berdasarkan hal di atas, maka peneliti melanjutkan penelitian yang dilakukan oleh Kurniadin \& Mardiono (2011), dengan menguji kelayakan minyak jelantah ditinjau penyerapan warna pada minyak goreng dan pada penelitian ini meninjau dari dari segi parameter bilangan peroksida dan asam lemak bebas, sehingga dapat diketahui apakah arang biji salak, dapat berpotensi dalam menurunkan angka peroksida dan asam lemak bebas dalam minyak jelantah, sehingga minyak jelantah dapat digunakan kembali.

\section{METODE PENELITIAN}

\section{Alat dan Bahan}

Alat yang digunakan yaitu gelas ukur, labu ukur, beker gelas, erlenmeyer, timbangan analitik, buret.

Bahan yang digunakan yaitu minyak goreng, biji salak, akuades, kertas saring, natrium hidroksida (NaOH) (Merck), etanol 95\% (Brataco), kloroform $\left(\mathrm{CHCl}_{3}\right)$ (Merck), indikator amilum (Merck), asam asetat $\left(\mathrm{CH}_{3} \mathrm{COOH}\right)$ (Merck), natrium tiosulfat $\left(\mathrm{Na}_{2} \mathrm{~S}_{2} \mathrm{O}_{3}\right)$ (Merck), indikator fenolftalin (Merck), dan larutan jenuh kalium iodida (KI) (Merck).

\section{Prosedur}

\section{Penyiapan Sampel Minyak Goreng}

Minyak yang digunakan dalam penelitian ini adalah minyak kemasan yang dipakai menggoreng hingga penggorengan ke-7. Minyak tersebut diperoleh dari pedagang makanan siap saji (Sari Laut) di salah satu warung makan jalan Basuki Rahmat, Palu, Sulawesi Tengah.

Minyak goreng yang masih dalam kemasan sebelum diberi perlakuan, disisipkan terlebih dahulu sebanyak $50 \mathrm{ml}$ untuk dianalisis sebagai kontrol. Dan sebanyak 2,5 liter dimasukkan ke dalam wajan penggorengan yang diletakkan di atas kompor gas dan akan dipakai untuk menggoreng bahan pangan. Proses $\begin{array}{llll}\text { penggorengan dilakukan sebanyak } & 7 & \text { kali }\end{array}$ menggunakan minyak yang sama pada temperatur $200^{\circ} \mathrm{C}$ selama 8 menit. Setiap kali penggorengan minyak akan diambil untuk selanjutnya dianalisis bilangan peroksida dan asam lemak bebasnya.

\section{Pembuatan Arang Biji Salak (Lestari, 2011)}

Biji salak diperoleh dari perkebunan salak di Desa Tamarenja, Kecamatan Sindue, Kabupaten Donggala, Sulawesi Tengah. Pertama-tama biji salak dibelah kecil-kecil dan dibersihkan, kemudian dikeringkan di bawah sinar matahari. Selanjutnya biji salak dimasukkan ke dalam tanur selama 2 jam pada suhu $400^{\circ} \mathrm{C}$ sampai biji salak menjadi arang. Setelah menjadi arang, dibiarkan dingin.

\section{Aktivasi dan Pengaplikasian Adsorben Arang Biji Salak}

Arang biji salak dihaluskan dan diayak menggunakan ayakan berukuran 100 mesh. Selanjutnya arang diaktivasi dengan $\mathrm{NaOH}$ 0,05 $\mathrm{N}$ kurang lebih 2 jam. Kemudian dicuci dengan akuades dan dikeringkan dalam oven pada suhu $105^{\circ} \mathrm{C}$. Setelah itu, arang biji salak didinginkan dalam desikator (Suryani, 2009).

Dalam pengaplikasian adsorben arang biji salak, sebanyak 50 gram sampel minyak dan arang ditimbang dengan perbandingan (4:1), 40 gram sampel minyak jelantah pada penggorengan ke tujuh ditimbang dengan teliti, kemudian masukkan ke dalam gelas kimia lalu panaskan. Setelah itu, tambahkan 10 gram arang biji salak, dan dilakukan pengadukan hingga tercapai suhu reaksi yang diinginkan yaitu suhu $70^{\circ} \mathrm{C}$. Selanjutnya, minyak didinginkan lalu dipisahkan dengan cara filtrasi. Kemudian filtrat di ambil dan dianalisis untuk melihat penenurunan kadar peroksida dan asam lemak bebasnya (Kurniadin \& Mardiono, 2011).

\section{Parameter Penelitian}

\section{Penentuan Bilangan Peroksida (AOAC, 1999)}

Ditimbang dengan teliti 5 gram sampel minyak goreng uji, ke dalam Erlenmeyer $250 \mathrm{~mL}$ kemudian ditambahkan $30 \mathrm{~mL}$ larutan asam asetat-kloroform (3:2), digoyangkan sampai bahan terlarut sempurna. Selanjutnya ditambahkan $0,5 \mathrm{~mL}$ larutan jenuh kalium iodida. Larutan selanjutnya didiamkan selama 1 menit kemudian tambahkan $30 \mathrm{~mL}$ akuades. Titrasi dengan larutan natrium tiosulfat 0,012 $\mathrm{N}$ hingga warna kuning hampir hilang. Kemudian tambahkan amilum 0,5 mL. Titrasi dilanjutkan sampai warna 
biru hilang. Kemudian hitung bilangan peroksida dalam minyak goreng uji.

$$
\text { Bilangan peroksida }=\frac{m L \mathrm{Na}_{2} \mathrm{~S}_{2} \mathrm{O}_{3} \times N \mathrm{Na}_{2} \mathrm{~S}_{2} \mathrm{O}_{3} \times 1000}{\text { berat sampel }(\mathrm{g})}
$$

\section{Penentuan Asam Lemak Bebas (Sudarmadji, 2007)}

Ditimbang dengan teliti 10 gram minyak goreng uji, kemudian masukkan ke dalam Erlenmeyer $250 \mathrm{~mL}$. Selanjutnya ditambahkan $50 \mathrm{~mL}$ etanol 95\%. Larutan kemudian dipanaskan sampai mendidih dan dikocok kuat untuk melarutkan asam lemak bebasnya, dinginkan. Setelah dingin, larutan ditambahkan indikator fenolftalin sebanyak 5 tetes, aduk dengan magnetic stirrer selama 30 detik. Setelah itu, dititrasi dengan larutan baku $\mathrm{NaOH}$ 0,102 N . Titik akhir titrasi tercapai apabila terbentuk warna merah muda yang tidak hilang selama 0,5 menit. Apabila cairan yang dititrasi berwarna gelap dapat ditambahkan pelarut yang cukup banyak. Kemudian hitung bilangan asam lemak bebas dalam minyak goreng uji.

$$
\begin{aligned}
& A L B=\frac{\mathrm{V} \mathrm{NaOH} \times \mathrm{N} \mathrm{NaOH} \times \mathrm{BM}}{m \times 1000} 100 \% \\
& \text { Keterangan: } \\
& \mathrm{V} \quad=\text { Jumlah mL KOH/NaOH untuk dititrasi } \\
& \mathrm{N} \quad=\text { Normalitas larutan } \mathrm{KOH} / \mathrm{NaOH} \\
& \mathrm{BM}=\text { Bobot molekul asam lemak } \\
& \mathrm{m} \quad=\text { berat sampel }(\mathrm{g})
\end{aligned}
$$

\section{Analisis Data}

Data yang diperoleh berupa kadar bilangan peroksida dan asam lemak bebas pada minyak goreng akan dianalisis secara statistik. Serta hasil tersebut akan dibandingkan dengan nilai Standar Nasional Indonesia (SNI) yang telah ditetapkan oleh Badan Standarisasi Nasional (BSN).

\section{HASIL DAN PEMBAHASAN}

Minyak goreng merupakan salah satu kebutuhan pokok manusia sebagai media pengolahan makanan. Minyak goreng adalah minyak yang berasal dari lemak tumbuhan atau hewan yang dimurnikan dan berbentuk cair pada suhu kamar. Minyak goreng banyak dimanfaatkan oleh masyarakat karena minyak goreng mampu menghantarkan panas, memberikan cita rasa (gurih), tekstur (renyah), warna (coklat), serta dapat meningkatkan nilai gizi produk (Ketaren, 2008).

Pemanfaatan minyak goreng sebagai media penghantar panas, sering kali menyebabkan perilaku yang kurang baik dari penggunanya, di mana minyak yang seharusnya hanya dapat digunakan 2-3 kali penggorengan, tetapi pada kenyataanya dipakai melebihi dari batas tersebut, hingga minyak berubah warna menjadi kecoklatan bahkan sampai kehitaman. Penggunaan minyak goreng berulang tidak hanya berdampak negatif pada minyak, tetapi juga berdampak pada keamanan minyak bagi kesehatan. Penggunaan minyak secara berulang-ulang sering kali dilakukan oleh masyarakat dengan alasan penghematan biaya.

Salah satu alternatif yang dapat dilakukan untuk meminimalkan penggunaan minyak secara berulangulang tanpa harus membeli minyak baru adalah dengan mendaur ulang minyak bekas pakai atau jelantah agar dapat digunakan kembali. Bahan yang dapat digunakan untuk mendaur ulang minyak jelantah adalah limbah biji salak. Berdasarkan penelitian Kurniadin \& Mardiono (2011), Penggunaan biji salak sebagai adsorben mampu menyerap partikel koloid pada minyak jelantah serta menjadi penyerap warna yang efektif dengan parameter pengujiannya yaitu uji organoleptis.

Biji salak dipilih karena keberadaannya sangat melimpah dan mudah didapatkan. Selain itu, di dalam biji salak mengandung selulosa. Selulosa mempunyai potensi yang cukup besar untuk dijadikan sebagai adsorben karena gugus -OH yang terikat pada selulosa, di mana apabila dipanaskan pada suhu tinggi akan kehilangan atom hidrogen dan oksigen sehingga tinggal atom karbon yang terikat membentuk segi enam dengan atom-atom karbon terletak pada setiap sudutnya (Adisesa, 1993).

Pada penelitian ini, digunakan biji salak sebagai adsorben untuk menetralisasi kenaikan bilangan peroksida dan asam lemak bebas yang terkandung pada minyak jelantah. Biji salak yang digunakan dalam penelitian ini adalah biji salak spesis salak pondoh yang dipisahkan antara daging buah dengan biji, setelah itu biji salak dicuci, dipotong kecil-kecil kemudian dikeringkan di bawah sinar matahari. Pengeringan ini bertujuan untuk meminimalkan kadar air yang terkandung dalam simplisia tersebut sehingga diharapkan terhindar dari tumbuhnya 
bakteri, jamur atau kapang pada penyimpanan yang cukup lama yang dapat menyebabkan rusaknya kandungan atau senyawa aktif dari simplisia.

Biji salak selanjutnya dikarbonisasi menggunakan tanur selama 2 jam pada suhu $400^{\circ} \mathrm{C}$. Karbonisasi merupakan suatu proses pembakaran tidak sempurna, sehingga bahan hanya terkarbonisasi dan tidak teroksidasi. Tujuan dari proses karbonisasi sendiri adalah untuk menghilangkan komponen-komponen yang terkandung di dalam sampel sehingga yang tersisa hanya arang atau karbonnya saja (Kinoshita, 1988).

Arang biji salak kemudian dihaluskan dan diayak menggunakan ayakan dengan ukuran 100 mesh. Proses pengayakan bertujuan untuk memperoleh ukuran partikel arang yang seragam sehingga semua arang biji salak dapat teraktivasi dan dapat diketahui kemampuan adsorptivitasnya pada proses adsorpsi antara adsorben dan adsorbat dengan ukuran partikel mesh yang telah ditentukan. Selanjutnya dilakukan proses aktivasi dengan cara merendam arang biji salak pada larutan pengaktivasi yaitu $\mathrm{NaOH} 0,05 \mathrm{~N}$ kurang lebih 2 jam. Proses aktivasi bertujuan untuk membuka atau memperbesar pori yaitu dengan cara memecahkan ikatan hidrokarbon atau mengoksidasi molekul-molekul permukaan sehingga arang mengalami perubahan sifat, baik fisika maupun kimia, yaitu luas permukaannya bertambah besar dan berpengaruh terhadap daya adsorpsi.

Arang yang telah diaktivasi kemudian dicuci dengan akuades dan dikeringkan dalam oven pada suhu $105^{\circ} \mathrm{C}$. Pencucian berfungsi untuk menghilangkan zat-zat pengotor yang ada pada serbuk arang biji salak serta untuk membebaskan arang dari ion $\mathrm{OH}$. Sedangkan pengeringan bertujuan untuk mengurangi kadar air yang terdapat pada arang aktif biji salak.

Netralisasi minyak jelantah menggunakan adsorben arang aktif biji salak dilakukan untuk mengetahui efektivitas dari biji salak dalam meningkatkan kembali mutu minyak goreng, sehingga minyak dapat digunakan kembali. Minyak yang digunakan pada penelitian ini adalah minyak kemasan. Minyak ini yang digunakan untuk menggoreng bahan pangan hingga penggorengan ke-7. Minyak hasil penggorengan ke-7 yang nantinya akan dinetralisasi menggunakan arang aktif biji salak. Tetapi, sebelum dilakukannya proses netralisasi minyak, maka terlebih dahulu dilakukan analisis awal terhadap kandungan asam lemak bebas dan angka peroksida pada minyak goreng sebagai kontrol. Dan minyak dengan penggorengan hingga 7 kali dianalisis kadar asam lemak bebas dan angka peroksida sebagai parameter untuk menguji tingkat kualitas minyak.

Kandungan asam lemak bebas dalam suatu minyak merupakan salah satu parameter penentu mutu minyak goreng. Semakin besar kadar asam lemak bebasnya, maka semakin rendah kualitas minyak goreng tersebut. Hasil analisis rata-rata kandungan asam lemak bebas yang terkandung dalam minyak goreng dapat dilihat pada Gambar 1, di mana terjadi kenaikan kandungan asam lemak bebas pada tiap pengulangan penggorengan. Dari data tersebut, terlihat kandungan rata-rata asam lemak bebas pada sampel minyak goreng sebelum penggorengan (kontrol) yaitu 0,0608\%, angka ini masih sangat jauh di bawah kadar yang disyaratkan oleh SNI. Sedangkan kandungan rata-rata minyak goreng setelah digunakan menggoreng mengalami tingkat kualitas yang menurun pada penggorengan ke-5 dengan nilai 0,3301\%. Hasil ini menunjukkan bahwa pada penggorengan ke-1, 2, 3, dan 4 kandungan asam lemak bebas masih memenuhi syaratSNI, tetapi pada penggorengan ke 5 - 7 kadar asam lemak bebas sudah melebihi kadar yang disyaratkan oleh SNI, yaitu $0,3 \%$.

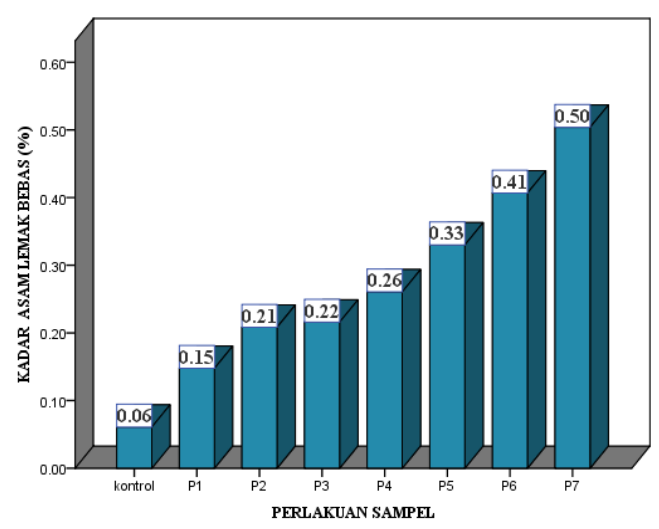

Gambar 1 Histogram Kadar Rata-Rata Asam Lemak Bebas Pada Minyak

Terbentuknya asam lemak bebas pada minyak dikarenakan terjadinya reaksi hidrolisis selama proses penggorengan. Proses hidrolisis mengakibatkan terjadinya peningkatan asam lemak bebas, monoacylglcerol, diacylglycerols dan gliserol (Osawa \& Gonçalves, 2012). Proses hidrolisis pada minyak goreng akan berlangsung semakin cepat apabila terdapat air di dalam bahan pangan yang digoreng (Hara et al., 2006). Adanya kandungan asam lemak 
bebas yang telah melebihi batas normal pada makanan hasil penggorengan akan mengakibatkan peningkatan inflamation systemic yang ditandai dengan munculnya interleukin-6 dan protein Creaktif yang berdampak pada gagal jantung dan kematian mendadak (Mozzaffarian et al., 2004). Selain meningkatkan asam lemak, pemanasan berulang akan membentuk asam lemak trans di dalam minyak (Fan et al., 2013). Beberapa penelitian menunjukkan bahwa konsumsi asam lemak trans mengakibatkan bahaya bagi kesehatan, seperti meningkatkan kolesterol LDL, menurunkan kolesterol HDL dan meningkatkan rasio total kolesterol (Stampfer et al., 1991). Selain itu konsumsi lemak trans mengakibatkan seseorang berisiko tinggi terkena penyakit diabetes dan jantung koroner (Oomen et al., 2001; Oh et al., 2005).

Parameter selanjutnya yang menjadi indikator terjadinya kerusakan minyak adalah adanya bilangan peroksida. Peroksida merupakan senyawa yang terbentuk karena adanya reaksi oksidasi pada minyak. Senyawa ini sangat labil dan mudah bereaksi. Kadar maksimal peroksida yang dipersyaratkan oleh SNI yang boleh terkandung pada minyak goreng adalah $10 \mathrm{meq} / \mathrm{kg}$. Dari hasil yang di peroleh setelah dilakukannya analisis angka peroksida terhadap minyak sebelum penggorengan (kontrol) dan setelah penggorengan ke-1, 2, 3, 4, 5, 6 dan 7, maka yang melebihi kadar yang telah ditetapkan oleh SNI yaitu minyak pada penggorengan ke-7, ini dapat dilihat pada Gambar 2, di mana angka peroksidanya mencapai $12,5492 \mathrm{meq} / \mathrm{kg}$.

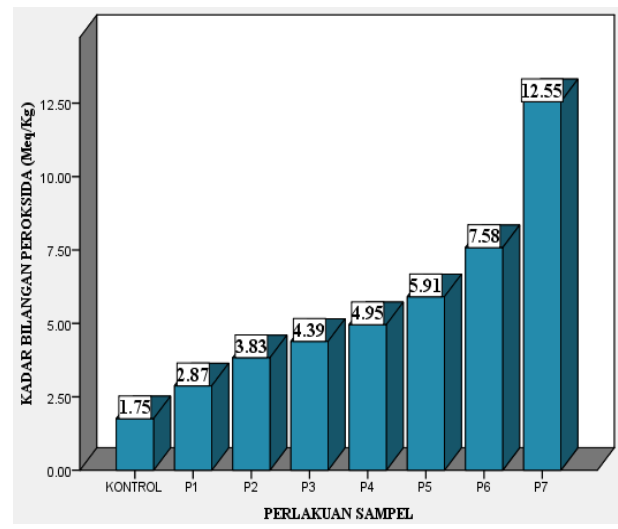

Gambar 2. Histogram Kadar Rata-Rata Angka Peroksida Pada Minyak.

Bilangan peroksida yang tinggi menandakan minyak telah teroksidasi. Menurut Ketaren (2008) peroksida dalam minyak goreng akan bertambah pada saat minyak yang sudah digunakan didinginkan dan peroksida akan mengalami dekomposisi kembali setelah proses pemanasan. Proses oksidasi minyak tidak hanya membentuk senyawa peroksida tetapi juga membentuk senyawa lain yaitu hidroperoksida, aldehid, keton, asam karboksilat, alkana rantai pendek dan alkena (Osawa \& Gonçalves, 2012). Beberapa studi telah dilakukan untuk mengkaji pengaruh penggunaan minyak jelantah terhadap kesehatan, yaitu keamanan bagi makhluk hidup. Pada minyak jelantah terdapat material tak berguna yaitu senyawa peroksida yang menyebabkan meningkatnya risiko terhadap beberapa penyakit, antara lain karsinoma, menimbulkan kerusakan hati dan membangkitkan respon peradangan hati. Mekanisme ini diduga berhubungan dengan radikal bebas yang akan berlanjut dengan terjadinya peroksidasi lipid (Oeije et al., 2007).

Data pengaruh netralisasi arang aktif biji salak terhadap penurunan kadar asam lemak bebas dan angka peroksida pada minyak jelantah dapat dilihat pada tabel 4.3, di mana rerata kadar awal asam lemak bebas sebelum netralisasi yaitu 0,5038\% dan rerata kadar setelah dinetralisasi adalah $0,1303 \%$. Jika data tersebut dipersentasikan sebagai persen penurunan kadar maka persentase penurunan kadar asam lemak bebas pada minyak jelantah mencapai 76,04\%. Sedangkan untuk angka peroksida diperoleh kadar awal yaitu 12,5492 meq/kg dan kadar setelah dinetralisai yaitu $5,5031 \mathrm{meq} / \mathrm{kg}$ dengan persentasi penurunan sebesar 56,18\%. Kadar rerata yang diperoleh setelah netrlisasi, jika disesuaikan dengan kadar maksimal yang dipersyaratkan oleh SNI, maka kadar tersebut masih di bawah kadar maksimal yang dipersyaratkan.

Persentase penurunan kadar asam lemak bebas, dapat disimpulkan bahwa penggunaan arang aktif biji salak memberikan persentase penurunan yang cukup baik terhadap kadar asam lemak bebas pada minyak jelantah. Hal ini dapat dilihat pada Gambar 3, di mana arang aktif biji salak tidak hanya memberikan penurunan terhadap minyak pada penggorengan ketujuh tetapi dapat pula memberi penurunan terhadap minyak pada penggorengan keenam hingga minyak pada penggorengan pertama. Sedangkan untuk grafik persentase penurunan angka peroksida dapat disimpulkan bahwa arang aktif biji salak hanya dapat memberi penurunan sebesar 50\% sehingga dapat dikatakan bahwa arang aktif biji salak kurang efektif dalam menurunkan angka peroksida minyak 
jelantah. Dan dapat dilihat pula pada Gambar 4, persentase penurunan angka peroksida bahwa arang biji salak hanya memberi pengaruh penurunan terhadap minyak pada penggorengan ke-5, 6 dan 7 sedangkan pada penggorengan ke-1 hingga ke-4 arang biji salak tidak memberi pengaruh sedikit pun terhadap penurunan angka peroksida.

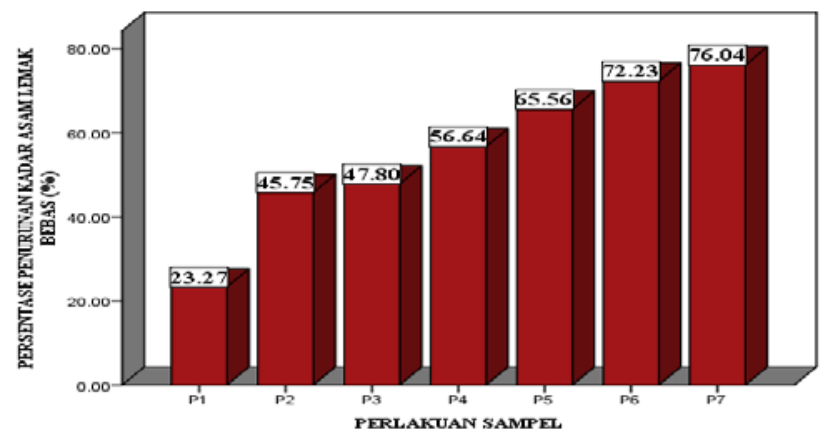

Gambar 3. Histogram Persentase Penurunan Asam Lemak Bebas.

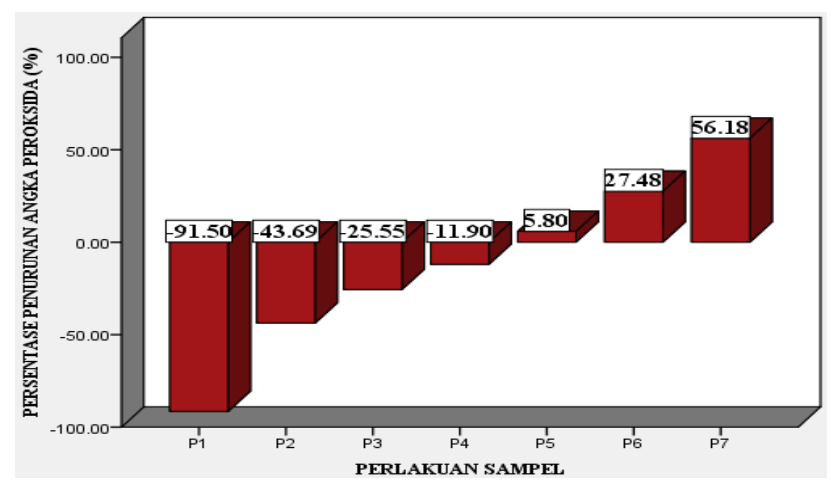

Gambar 4. Histogram Persentase Penurunan Angka Peroksida.

Data selanjutnya dianalisis menggunakan analisis varian satu arah (ANOVA). Dari hasil uji test of homogenety of variances menunjukan bahwa persentase penurunan kadar asam lemak bebas mempunyai nilai signifikasi $>0,05(0,192>0,05)$, maka dapat dikatakan bahwa ketujuh kelompok perlakuan mempunyai varian yang sama (homogen). Setelah diketahui ketujuh varian terbukti sama, maka dilakukan uji anova lanjutan untuk mengetahui apakah ketujuh perlakuan mempunyai rata-rata yang sama. Berdasarkan uji anova yang diperoleh terlihat bahwa F hitung > F tabel $(26,384>2,85)$ yang berarti bahwa Ho ditolak dan Ha diterima. Maksudnya adalah terdapat perbedaan rata-rata kandungan asam lemak bebas pada masing-masing kelompok perlakuan. Sedangkan untuk nilai probabilitas, diperoleh 0,000 yang menunjukan probabilitas <
0,05, dengan demikian hipotesis nol (Ho) ditolak. Hal ini menunjukkan bahwa data yang diperoleh signifikan, yang artinya ada pengaruh perlakuan penggorengan terhadap penurunan kandungan asam lemak bebas pada minyak goreng. Karena terdapat perbedaan rata-rata antar kelompok perlakuan sehingga analisis data dilanjutkan dengan uji analisis Post Hoc. Post Hoc dilakukan untuk mengetahui kelompok mana yang berbeda dan yang tidak berbeda. Atau dapat dikatakan dalam kasus ini, kelompok penggorengan mana yang memberikan pengaruh signifikan terhadap penurunan kadar asam lemak bebas. Uji Post Hoc merupakan uji kelanjutan dari uji ANOVA jika hasil yang diperoleh pada uji ANOVA adalah $\mathrm{H}_{0}$ ditolak atau terdapat perbedaan antara tiap kelompok.

Berdasarkan analisis statistik One Way Anova dan dilanjutkan dengan uji lanjut Post Hoc Tukey dapat disimpulkan bahwa penggorengan pertama menunjukkan penurunan yang paling baik karena dapat menurunkan kadar asam lemak bebas sebesar 23,27\%, kemudian diikuti penggorengan ke-2 hingga ke-4 yang memberi penurunan sebesar 45 - 56\%. Kadar ini merupakan kadar maksimal yang dapat digunakan untuk menggoreng. Sedangkan pada penggorengan ke-5 hingga ke-7 minyak sudah dikatakan rusak atau tidak dapat digunakan lagi.

Sedangkan, untuk data kandungan peroksida pada minyak goreng tidak dapat diuji menggunakan anova hal ini dikarenakan data yang diperoleh tidak homogen. Sehingga peneliti mengambil alternatif yaitu dengan menguji data tersebut menggunakan uji non-parametrik. Hasil uji nonparametrik menggunakan Kruskall Wallis terlihat bahwa kolom Asymp.sig bernilai 0,004, yang mana nilai tersebut < 0,05, maka Ho ditolak. Hal ini berarti terdapat perbedaan nyata pada masing-masing perlakuan sampel.

\section{UCAPAN TERIMA KASIH}

Terima kasih saya ucapkan kepada semua pihak yang telah membantu dalam penyelesaian penelitian ini.

\section{DAFTAR PUSTAKA}

Adisesa, H.T. (1993). Beberapa Perubahan Struktur dalam Selulosa pada Pengeringan. Tesis Magister Kimia. Institut Teknologi Bandung. Bandung. 
AOAC. (1999). Official Methods of Analysis of the Association of Official Analytical Chemist International. Washington: $16^{\text {th }}$ ed. AOAC Inc.

Fan, H. Y. C., Shaarani, S., Mamat, H., \& Chiew, H. (2012). Frying stability of rice bran oil and palm olein. International Food Research Journal, 20, 403-407.

Hara, S., Ogawa, E., \& Totani, Y. (2006). Evaluation of Heat-deteriorated Oils. I. TLC-FID Method for Determining Polar Compounds Content. Journal of Oleo Science, 55(4), 167-172.

Ketaren, S. (2008). Pengantar Teknologi Minyak Dari Lemak Pangan. Jakarta: UI Press.

Kinoshita, K. (1988). Carbon: Electrochemical and Physicochemical Properties. United States.

Kurniadin, A., \& Mardiono. (2011). Penjernihan Minyak Goreng Bekas dengan Proses Adsorbsi Menggunakan Arang Biji Salak. Skripsi. Universitas Diponegoro, Semarang.

Kusumastuti. (2004). Kinerja Zeolit dalam Memperbaiki Mutu Minyak Goreng Bekas. Jurnal Teknologi dan Industri Pangan, 15(2): 141-144.

Lestari, R. (2011). Pembuatan Biocharcoal dari Kulit Pisang untuk Penyerapan Logam Timbal $(\mathrm{Pb})$ dan Seng (Zn). Skripsi. Program Studi Pendidikan Kimia Universitas Tadulako. Palu.

Mozaffarian, D., Pischon, T., Hankinson, S. E., Rifai, N., Joshipura, K., Willett, W. C., \& Rimm, E. B. (2004). Dietary intake of trans fatty acids and systemic inflammation in women. The American Journal of Clinical Nutrition, 79(4), 606-612.

Oeije, AA., Lukita, AW., Achmad, S., \& Tohardi, A. (2007). Gambaran Anatomi Mikroskopik dan Kadar Melondialdehida pada Hati Mencit Setelah Pemberian Minyak Kelapa Sawit Bekas Menggoreng. Jurnal Kedokteran Maranatha. 7(1), 15-25.

Oh, K. Hu, F. B., Manson, J. E., Stampfer M. J., \& Willett, W. C. (2005). Dietary Fat Intake and Risk of Coronary Heart Disease in Women: 20 Years of Follow-up of the Nurses' Health
Study. American Journal of Epidemiology, 161(7), 672-679.

Oomen, C. M., Ocké, M. C., Feskens, E. J., ErpBaart, M.-A. J. van, Kok, F. J., \& Kromhout, D. (2001). Association between trans fatty acid intake and 10-year risk of coronary heart disease in the Zutphen Elderly Study: A prospective population-based study. The Lancet, 357(9258), 746-751.

Osawa, C. C., \& Gonçalves, L. A. G. (2012). Changes in breaded chicken and oil degradation during discontinuous frying with cottonseed oil. Food Science and Technology, 32(4), 692-700.

Rahayu, L.H., Sari, P., \& Herman Y, S., (2014). Potensi Sabut dan Tempurung Kelapa Sebagai Adsorben Untuk Meregenerasi Minyak Jelantah. Akademi Kimia Industri "Santo Paulus”. Semarang.

Reski, A. (2012). Studi Kualitas Minyak Makanan Gorengan pada Penggunaan Minyak Goreng Berulang. Jurusan Teknologi Pertanian Fakultas Pertanian Universitas Hasanuddin. Makassar.

Stampfer, M. J., Sacks, F. M., Salvini, S., Willett, W. C., \& Hennekens, C. H. (1991). A Prospective Study of Cholesterol, Apolipoproteins, and the Risk of Myocardial Infarction. New England Journal of Medicine, 325(6), 373-381.

Sudarmaji, S. (2007). Analisa untuk Bahan Pangan dan Pertanian. Yogyakarta: Liberty.

Suryani, A.M. (2009). Pemanfaatan Tonggol Jagung untuk Pembuatan Arang Aktif Sebagai Adsorben Pemurniaan Minyak Goreng Bekas. Skripsi. Departemen Kimia Institut Pertanian Bogor. Bogor.

Wijana, S. (2005). Teknopangan: Mengolah Minyak Goreng Bekas. Surabaya: Penerbit Trubus Agrisarana.

Yustinah. (2011). Adsorbsi Minyak Goreng Bekas Menggunakan Arang Aktif Dari Sabut Kelapa. Prosiding Seminar Nasional Teknik Kimia. Yogyakarta. 